\title{
ANALYSIS OF FACTORS AFFECTING THE IMPLEMENTATION OF FINANCIAL ACCOUNTING STANDARDS FOR MICRO, SMALL AND MEDIUM ENTITIES (SAK-EMKM) ON SHARIA- BASED MSMES
}

\author{
Zuliyati $^{1^{*}}$, Indrianingrum $^{2}$ \\ *Corresponding Author \\ ${ }^{1}$ Department of Accountancy, University of Muria Kudus, Kudus, Central Java, Indonesia, zuliyati@ umk.ac.id \\ ${ }^{2}$ Department of Accountancy, University of Muria Kudus, Kudus, Central Java, Indonesia, 201612248@ std.umk.ac.id
}

\begin{abstract}
This research analyzed the effects of owner perceptions, education, socialization, business scale, and business age on applying the Accounting Standards for Micro, Small, and Medium Enterprises (SAK EMKM) on sharia-based MSMEs in Kudus Regency. This qualitative study used primary data from respondents. The researchers collected the data via questionnaires. The technique of analysis was multiple linear regression. The researchers used purposive sampling based on the criteria of Sharia-based MSMEs in the Kudus Regency. The result was - the sample consisting of 100 participants. The results showed that the variable owner perception, business scale, and business age did not affect the application of SAK EMKM. Education and socialization had a positive effect on the implementation of SAK EMKM. The study limitations were the independent variable and the object. The independent variable was only the influence of SAK EMKM by $28 \%$, while the object consisted only of the Sharia-based MSMEs in the Kudus regency.
\end{abstract}

Keywords: owner's perception, socialization, business scale, business age, implementation of SAK EMKM, sharia-based MSMEs

Received

January 28, 2021

To cite this article:
Revised

August 23, 2021
Accepted

September 7, 2021
Published

September 30, 2021

Zuliyati \& Indrianingrum (2021). Analysis of factors affecting the implementation of financial accounting standards for micro, small and medium entities (SAK-EMKM) on sharia based MSMEs. IJIBE (International Journal of Islamic Business Ethics), 6 (2), 79-91. http://dx.doi.org/10.30659/ijibe.6.2.79-91

\section{INTRODUCTION}

The very rapid development of technology demands renewal in the economic field. The economic reform gives rise to a concept, namely a sharia-based creative economy. The concept intensifies information using ideas and knowledge from Human Resources (HR), which do not deviate from Islamic teachings. The creative economy produces products and services, and processes (Stasiulis \& Technical, 2017). In recent years, the need to think, adapt and explore creative industry opportunities in countries with significant economic changes today (Yuriy B, Tetyana V, Olena K \& Tomas, 2019). Creative industries involve all parties in developing the economy(Cerneviciute \& Strazdas, 2018). The success of the creative industries allows us to ignore or underestimate some of the less exciting innovations (Banks \& Connor, 2017). This creative economy consists of small-scale businesses such as Micro, Small, and Medium Enterprises (MSMEs).

Financial reports have many benefits for the doers, such as planning the business in the future, calculating the profit and loss from the monthly and annual sales, calculating annual taxes quickly, determining the financial position to make a decision. However, most MSME 
doers perceive that financial reports are not crucial for their business. Moreover, the doers are also lack understanding and information related to the financial statements they receive (Galuh Artika Febriyanti, 2018). It influences the financial report implementation based on the applied standards. The incapability of the doers to compile financial reports is correlated to the owner perception, education, socialization, business scale, and life of the business.

The socialization and educational background positively influenced the understanding of SMEs doers about SAK EMKM. On the other hand, the firm's scale and business life did not influence the understanding of SMEs business people about SAK EMKM (Adino, 2019). Perception deals with a person's perspective of seeing something. This matter also refers to a person's view or understanding in interpreting something. Formally, perception is the process of a person selecting, organizing, and interpreting an object into a broader, comprehensive, and meaningful world. It is a causal factor toward the implementation of SAK EMKM in MSMEs. Galuh Artika Febriyanti (2018) argues that perception has a positive and significant effect on the application of SAK EMKM.

Many sharia-based MSMEs multiply and contribute to the economy in Indonesia. The creativity of MSMEs has a strategic role in the development and growth (Bhansing et al., 2017). The example of the strategic roles is the employment, the equal development distribution, the increased National Gross Domestic Product (GDP), and the driving pilot of the economy of Indonesian society. Most Indonesian people are Muslims. Therefore, the role of MSMEs in economic growth in Indonesia is to produce valuable outputs for the community, including sharia-based MSMEs in the City of Kudus. The growth rate of MSMEs in this city increases annually by 3.4\%, 15, with 300 MSMEs (Data of MSMEs Department, 2018). The presence of MSMEs in Kudus drives the economy of the Kudus area. The regional government develops a sharia-based creative economy by producing halal and star's creative economic products through cooperation with sharia institutions and Penta helix elements (Reno \& Rahman, 2019).

The number of MSMEs in the Kudus Regency has increased significantly, namely around 3.4\% each year. According to the Department of Manpower, Industry, Cooperatives, and MSME, many MSMEs in the Kudus Regency reach 15,300 businesses. Therefore, to improve the quality of MSMEs both in production and management, it is hoped that MSMEs in Kudus Regency can accept the Financial Accounting Standards for Micro, Small, and Medium Entities (SAK-EMKM). These standards are aimed explicitly at MSMEs in making financial reports to make it easier and simpler. Human capital research has a significant effect on MSME performance (Delima \& Zuliyati, 2020).

The difference between this research with research conducted by Febriyanti and Wardhani (2018) is the addition of business scale variables and prolonged efforts to apply SAK EMKM. This object is different from previous research, which focuses on sharia-based MSMEs, where products produced and sold are limited to halal food products and Muslim fashion convection products and hijabs for Muslims. The owners/doers of MSMEs need to apply SAK EMKM in creating and presenting financial statements so that there are no irregularities and misrepresentations in financial statements made to fulfill specific interests.

\section{LITERATURE REVIEW}




\section{Needs Theory}

This research is based on the theory of needs developed by Clayton Alderfer from Yale University, who argues that humans have three groups of core needs, namely existence, relationship, and development. Existence in this study is the need to live following low levels of need, namely physiological needs and the need for security. Relatedness (relationship) is the need to interact with others. Everyone wants to associate their existence with other people and the circumstances around them. In terms of business, the interaction between business owners and employees and with customers is needed. This continuing relationship will result in the existence of a business being recognized. Growth is a need that encourages a person to have a creative and productive influence on oneself or the environment. In the case of a job or profession, someone who wants to get success, progress, or achievement exceeds what has been previously achieved, which is assessed by standards. These standards can come from themselves or general standards that have been set.

\section{Micro, Small and Medium Enterprises (MSME)}

Law Number 20 the Year 2008 about MSMEs regulates and defines the criteria of Micro, Small, and Medium Enterprises. Firstly, the Law defines micro-business groups as productive businesses owned by individuals and or individual business entities based on the regulated criteria by the Law. Then, small businesses are independent, productive economic enterprises by individuals or business entities. The small businesses are not subsidiaries or not branches of medium and large companies, both directly and indirectly. Thirdly, the medium business refers to a medium-sized business. This business is a productive economic and independent enterprise by individuals or business entities. The business is not subsidiaries or branches of companies that are owned, controlled or are part of small or large businesses directly or indirectly in terms of net assets or annual sales as regulated by the Law.

\section{Financial Report according to SAK EMKM}

According to SAK EMKM (2018), financial statements inform an entity's financial position and performance. It is useful for many users who do not have positions to request specific financial reports to make economic decisions and meet these information needs. These users include resources for the entity, such as creditors and investors. Financial statements also show the accountability of management for the resources entrusted to it. Items in the financial statements based on SAK EMKM are assets, liabilities, income, and expenses.

Based on SAK EMKM (2018), the minimum financial statements include (a) financial position report at the end of the period; (b) profit and loss for the period; and (c) notes to financial statements, with additional additions and details of certain relevant items. MSMEs owner can encourage himself or herself to record and use the accounting information. The owner must also have the responsibility to prepare financial statements for external parties (Kamila, 2017).

\section{Research Variable}

The dependent variable in this study is the application of SAK EMKM (Y). SAKEMKM is an applied standard to micro, small and medium enterprises as a simplification of 
SAK-ETAP. It facilitates the preparation of financial reports and bank access. The researchers used 10 statement items developed by Tarmizi and Bugawanti (2013) and with three indicators. They are accountability, objectives, and characteristics of completeness of the information. The researchers used the Likert scale to measure the variable.

The independent variable in this study is perception (X1). The perception of MSMEs owners is an individual's learning process through prejudice from information both listening and observing. The researchers used a questionnaire developed by Tarmizi \& Bugawanti (2013). It consisted of 10 statements and three indicators. They were attitude, habit, and will. The researcher used the Likert scale to measure the variables.

Education Level (X2) is an independent variable that affects MSMEs' SAK EMKM implementation. Education is a process of learning and mastering skills that involves researching and training. The educational level reflects creativity (Weingarten \& Meyer, 2020). The researchers used a questionnaire developed by Lohanda (2017). It consisted of 10 statements and three indicators, including education level, department suitability, and competence. The researchers used the Likert scale to measure this variable.

Socialization (X3) is the third independent variable. SAK-EMKM socialization is a process of the individual to adapt, coordinate, behave, and learn based on the roles and rules of SAK-EMKM. The researcher adopted the questionnaire of Kusuma \& Luthfiany (2018). It consisted of 6 statements and two indicators. They were the implementation of socialization and knowledge related to SAK EMKM. The researchers used the Likert scale to measure this variable.

Business Scale (X4) is the fourth independent variable. The business scale is the size of a business based on the sales, profits, and number of employees. The researchers adopted Soraya's questionnaire (2016). It consisted of 3 question items and three indicators. They were the number of employees, assets, and sales results during the year. The researchers used the Likert scale to measure this variable.

Business life (X5) is the fifth independent variable. It refers to the time for the business to establish until the research promotion. Kazungu (2020) explains that longer business life creates a wider and broader network, so the financial administration is excellent. The researchers modified Soraya's questionnaire (2016). It consisted of 1 question and one indicator, namely the business's life during the investigation until the research promotion.

The use of measurement of variables is carried out with a Likert scale.

\section{Hypothesis Formulation}

The hypotheses in this study are:

H1: The perception of MSMEs owners has a positive effect on the implementation of SAK EMKM.

$\mathrm{H} 2$ : The education of MSMEs doers has a positive effect on the implementation of SAK EMKM.

H3: SAK EMKM socialization has a positive effect on the implementation of SAK EMKM.

H4: Business size has a positive effect on the implementation of SAK EMKM.

H5: Business life has a positive effect on the implementation of SAK EMKM.

The frame of mind is depicted in Figure 1 below. 
Figure 1: A research framework

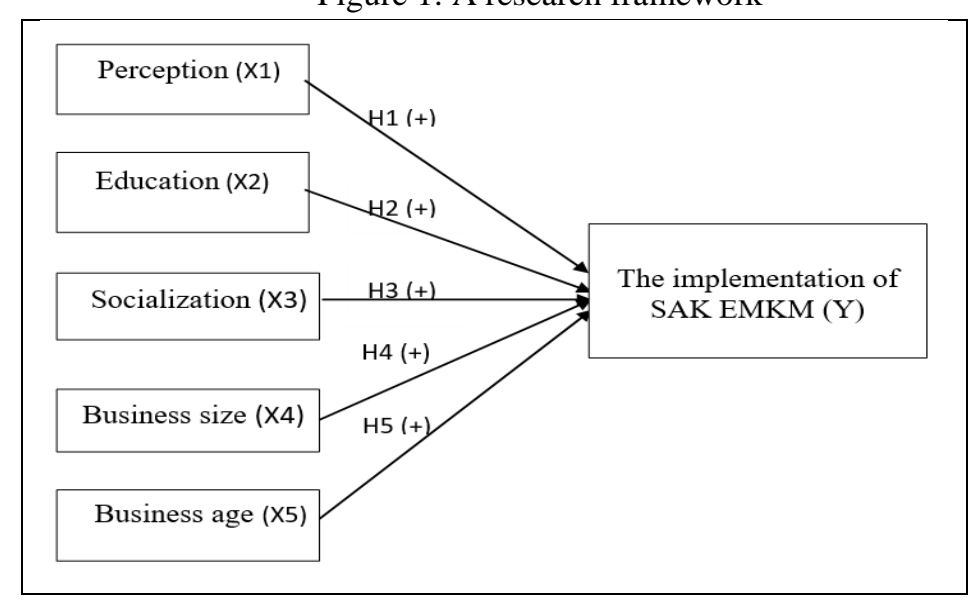

Source: Febriyanti and Wardhani (2018) and Soraya and

Mahmud (2016) are modified (2020)

\section{METHOD}

The types and sources of data used in this study are primary data, distributing questionnaires to sharia-based SMEs doers in Kudus Regency. The population taken in this study was 15,300 MSME doers in Kudus Regency (according to data from the UMKM Office of Kudus district 2018). The sampling technique used in this study is purposive sampling. By using certain criteria (Indriantoro, 1999: 130), namely, sharia-based MSMEs with the type of food and beverage business that has a halal license, Muslim clothing, and hijab convection, and other types of businesses with Muslim business owners. The sample used is 100 respondents. The profiles of respondents based on the type of business are as follows:

Table 1: Profile of Respondents by Type of Business

\begin{tabular}{|l|l|l|l|}
\hline Num & \multicolumn{1}{|c|}{ Type of Business } & Total & Percentage \\
\hline 1. & Batik, convection, embroidery & 21 & $21 \%$ \\
\hline 2. & Service & 12 & $12 \%$ \\
\hline 3. & Foods and Drinks & 26 & $26 \%$ \\
\hline 4. & Trade/Shop & 23 & $23 \%$ \\
\hline 5. & Iron, copper, coal & 8 & $8 \%$ \\
\hline 6. & Handicraft & 6 & $6 \%$ \\
\hline 7. & Agriculture / Livestock & 4 & $4 \%$ \\
\hline & Number of Respondents & 100 & $100 \%$ \\
\hline
\end{tabular}

Source: Primary Data Processed by SPSS 25, 2020

Hypothesis testing for this study uses multiple linear analysis techniques, which are used to determine how much influence the independent variable has on the dependent variable. Afterward, there is a causal relationship of more than one independent variable with one dependent variable. The multiple linear regression model in this study uses the unstandardized regression coefficient B on the simultaneous effect analysis and standardized beta on the partial effect analysis. 


\section{RESULT}

\section{Descriptive Statistics}

Descriptive statistics describe the answers from respondents regarding the research variables, such as perception, education, socialization, business scale, and business life. It describes the average (mean), standard deviation, variance, maximum, minimum, and sum (Ghozali, 2016: 19).

Table 2 provides the results of descriptive statistics, started from the mean, minimum, maximum, and standard deviation values. The higher average value than the standard deviation value indicates that the respondents' answers are nearly similar.

Table 2: Descriptive Statistical Analysis Test Results

\begin{tabular}{|c|c|c|c|c|c|c|}
\hline & $\mathrm{N}$ & Minimum & Maximum & Sum & Mean & $\begin{array}{c}\text { Std } \\
\text { Deviation }\end{array}$ \\
\hline $\mathrm{X} 1$ & 100 & 26 & 50 & 3788 & 37,88 & 5,576 \\
\hline $\mathrm{X} 2$ & 100 & 10 & 50 & 3565 & 35,65 & 5,844 \\
\hline $\mathrm{X} 3$ & 100 & 12 & 30 & 2179 & 21,79 & 3,875 \\
\hline $\mathrm{X} 4$ & 100 & 3 & 11 & 366 & 3,66 & 1,380 \\
\hline $\mathrm{X} 5$ & 100 & 1 & 5 & 207 & 2,07 & 1,273 \\
\hline $\mathrm{Y}$ & 100 & 15 & 50 & 3213 & 32,13 & 6,096 \\
\hline $\begin{array}{c}\text { Valid N } \\
\text { (listwise) }\end{array}$ & 100 & & & & & \\
\hline
\end{tabular}

Source: Primary Data processed by SPSS 25, 2020

\section{Data Quality Test Results}

The reliability test examines whether the questions and statements can measure the variables. The researcher did it by measuring the indicators of the questionnaire. A reliable questionnaire must have consistent and stable answers from the individuals' answers. The other indication of reliability is the consistent respondent's answers. However, if the answer is random, the questionnaire is deemed unreliable (Ghozali, 2016: 47).

The validity test shows that all items have a higher R-value than the $r$-table ( $r$ count $>$ 0.1966). Thus, the variable perception meets the validity requirement. The researchers determined the reliability from the Cronbach's Alpha. The values for the perception are 0.913 , education with 0.878 , socialization 0.889 , business scale 0.633 , business life 1,000 , and application of SAK EMKM 0.887. Thus, all statements in the questionnaire are reliable because the value of Cronbach's Alpha is greater than 0.60.

\section{Classical Assumption Test Results}

Regression test requires classical assumption test to ensure the regression model requirement. The test consisted of normality, multicollinearity, and heteroscedasticity tests.

Table 3 shows that the normality test. The researcher used the One-Sample Kolmogorov-Smirnov test and obtained an Aysmp Sig of $0.098>0.05$. Thus, the data distribution is normal. 
Table 3: Normality Test Results

\begin{tabular}{|c|c|}
\hline \multicolumn{2}{|c|}{ One Sample Kolomogrov-Smirnov Test } \\
\hline & Unstandardized Residual \\
\hline $\mathrm{N}$ & 100 \\
\hline Asymp. Sig (2-tailed) & 0,098 \\
\hline
\end{tabular}

Source: Primary Data Processed by SPSS 25, 2020

Table 4 shows no multicollinearity for the equation model in this study. The indication is on the VIF score $>0.1$ and VIF score $<10$.

Table 4: Multicollinearity Test Results

\begin{tabular}{|l|l|l|l|}
\hline \multirow{2}{*}{ Variable } & \multicolumn{2}{|c|}{ Collineariyt Statistic } & \multirow{2}{*}{ Explanation } \\
\cline { 2 - 3 } & Tolerance & VIF & \\
\hline Perception & 0,493 & 2,028 & Multicollinearity Free \\
\hline Education & 0,837 & 1,195 & Multicollinearity Free \\
\hline Socialization & 0,527 & 1,896 & Multicollinearity Free \\
\hline Business Scale & 0,955 & 1,047 & Multicollinearity Free \\
\hline Business life & 0,933 & 1,072 & Multicollinearity Free \\
\hline \multicolumn{2}{|l|}{ Source: Primary Data Processed by SPSS 25, 2020 } \\
\hline
\end{tabular}

Table 5 shows that the significance value of the correlation between the independent variables and their absolute residuals. The value is higher than the significant calculated level, 0.05. Thus, the data obtained does not have any heteroscedasticity.

Table 5: Heteroscedasticity test results

\begin{tabular}{|l|l|}
\hline \multicolumn{1}{|c|}{ Variable } & Significant \\
\hline Perception (X1) & 0,802 \\
\hline Education (X2) & 0,281 \\
\hline Socialization (X3) & 0,771 \\
\hline Business Scale (X4) & 0,381 \\
\hline Business life (X5) & 0,700 \\
\hline \multicolumn{2}{|l|}{ Source: Primary Data Processed by SPSS 25, 2020 }
\end{tabular}

\section{Multiple Linear Regression Analysis}

Hypothesis testing for this study uses multiple linear analysis techniques to determine the influence of the independent variable toward the dependent variable. The result found a causal correlation of more than one independent variable with one dependent variable. The multiple linear regression model in this study used the unstandardized regression coefficient $\mathrm{B}$ on the simultaneous effect analysis and standardized beta on the partial effect analysis (Ghozali, 2016).

Multiple linear regression test determines the effect of the independent variable on the dependent variable. Table 6 shows the results of the calculation of multiple linear regression analysis. The regression equation is follows:

$Y=8,073+0,154 X 1+0,194 X 2+0,548 X 3-0,039 X 4-0,239 X 5+e$ 
Table 6. Multiple linear regression

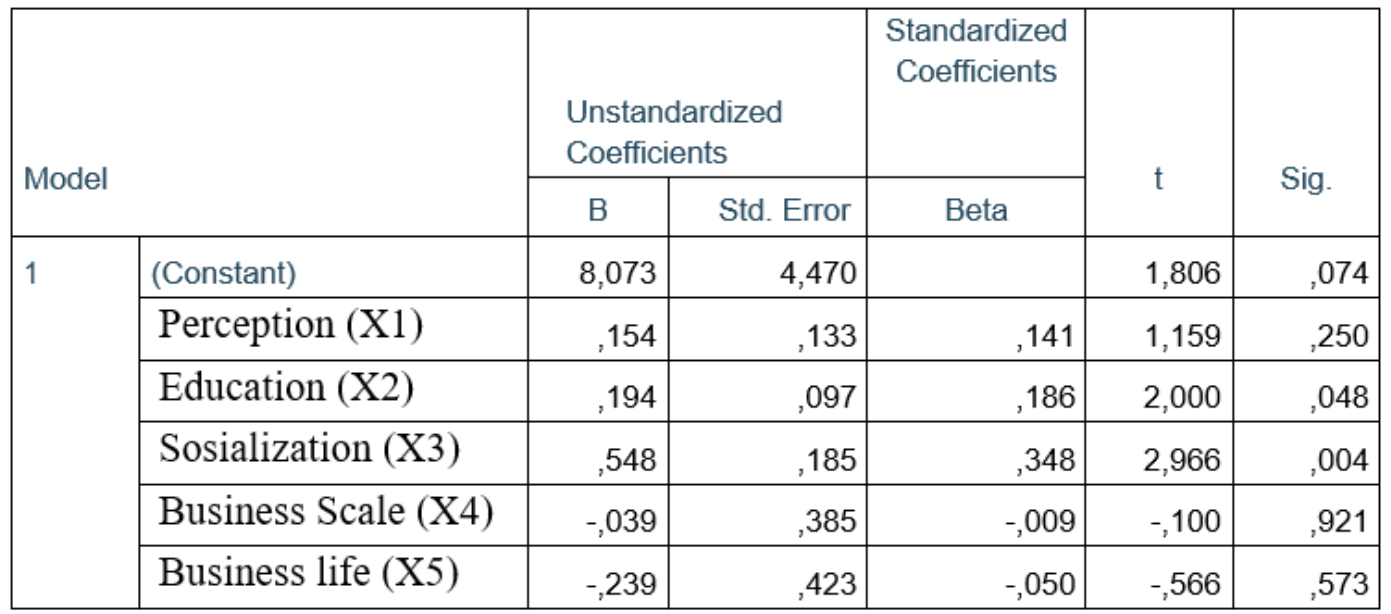

Source: Primary Data Processed by SPSS 25, 2020

The value 8,073 means the variables of perception, education, socialization, business scale, and business life are constant (0) increases the average application of SAK EMKM by 8.073.

The positive regression coefficient value of the perception variable, 0.154 , indicates each $1 \%$ increase in perception increases the application of SAK EMKM by $0.154 \%$. It is under the assumption that the other independent variables are considered constant. The positive regression coefficient value of the education variable, 0.194 , indicates each $1 \%$ increase in education increases the application of SAK EMKM by $0.194 \%$. It is under the assumption that the other independent variables are considered constant. The socialization variable is positive, 0.548 . It indicates that each $1 \%$ increase in socialization increases the application of SAK EMKM by $0.548 \%$. It is under the assumption that the other independent variables are considered constant. The negative regression coefficient value of the business scale, -0.039 , shows each $1 \%$ increase in business scale decreases the implementation of SAK EMKM by $0.039 \%$. It is under the assumption that the other independent variables are considered constant. The business life variable has a negative sign, -0.239 . It shows each $1 \%$ increase in business life, the implementation of SAK EMKM decreases by $0.239 \%$.

\section{Coefficient of Determination $\left(R^{2}\right)$}

The coefficient of determination measures the model's ability to explain the variation in the dependent variable. The coefficient of determination is zero and one. There is a fundamental weakness in using the coefficient of determination, such as bias towards the number of independent variables. Therefore, this study used the adjusted values to evaluate the best regression models. The adjusted values fluctuate due to the addition of an independent variable into the model. It is different from the empirical test with its an adjusted negative value. In this test, the adjusted value is considered to be 0 .

The coefficient of determination is observable from the adjusted $R$ square value in the regression model. Table 7 shows the results of the adjusted $\mathrm{R}$ square coefficient: 
Table 7: The Result of The Determination Coefficient Test

\begin{tabular}{|c|l|l|}
\hline $\mathrm{R}$ & R Square & Adjusted R Square \\
\hline 0,563 & 0,317 & 0,280 \\
\hline
\end{tabular}

Source: Primary Data Processed by SPSS 25, 2020

Table 7 shows the Adjusted R Square value is 0.280 . The results of the adjusted $\mathrm{R}$ square show that perception, education, socialization, business scale, and business life as independent variables can explain the effect of the dependent variable by $28 \%$. The remaining percentage, $72 \%$, refers to unobserved variables.

\section{Simultaneous Test with F-test}

The simultaneous test determines the joint effect of the independent variable on the dependent variable by using the F-test. This test used a significance level of 0.05

Table 8 shows the results of the F-test with $\mathrm{F}$ count $>\mathrm{F}$ table. The $\mathrm{F}$ count is $8.713>\mathrm{F}$ table, 2.32. The $\mathrm{f}$ table value's calculation is df $1=\mathrm{k}-1(6-1)=5$, df $2=\mathrm{nk}(100-6)=94$ with a significant value $(p)=000$. Based on the provisions of the $F$ test with the probability value is $<0.05$, the variables of perception, education, socialization, business scale, and business life have a significant effect on the application of SAK EMKM.

Table 8: Result Test of F Statistics

\begin{tabular}{|l|l|l|}
\hline Model & F & Sig. \\
\hline Regression & 8,713 & $000^{\mathrm{b}}$ \\
\hline
\end{tabular}

Source: Primary Data Processed by SPSS 25, 2020

\section{Partial Test with t-Test}

T-test examines the influence of each independent variable (X) on the dependent variable (Y). The hypothesis used a significance level of $\alpha=5 \%$ in two directions.

Table 9: Result Test of t Statistics

\begin{tabular}{|l|l|l|}
\hline \multicolumn{1}{|c|}{ Hypothesis } & T & Sig \\
\hline Owner's perception has a positive effect on the implementation of SAK EMKM (H1) & 1,159 & 0,250 \\
\hline Education has a positive effect on the implementation of SAK EMKM (H2) & 2,000 & 0,048 \\
\hline Socialization has a positive effect on the implementation of SAK EMKM (H3) & 2,966 & 0,004 \\
\hline Business Scale has a positive effect on the implementation of SAK EMKM (H4) & $-0,100$ & 0,912 \\
\hline Business life has a positive effect on the implementation of SAK EMKM & $-0,566$ & 0,573 \\
\hline
\end{tabular}

Source: Primary Data Processed by SPSS 25, 2020

Table 9 shows the results of the $t$ statistical test with a significance level of $a=0.05$, the degree of freedom $(\mathrm{df})=\mathrm{nk}-1$ or 100-5-1 (94), t-table 1.66123 then the results of the $\mathrm{t}$ statistical test are as follows.

Perception has a significance value of $0.205>0.05$ and $t 1.159$. It means that 
perceptions do not affect SAK EMKM. The hypothesis H1, stating that perceptions positively affect the application of SAK EMKM, is rejected. Education has a significant value of 0.048 lower than 0.05 and t 2,000. It shows that education affects SAK EMKM. The hypothesis $\mathrm{H} 2$, stating that education has a positive effect on the application of SAK EMKM, is accepted.

Socialization has a significant value of 0.004 less than 0.05 and $t 2.966$. It shows that socialization affects the implementation of SAK EMKM. The hypothesis H3, socialization has a positive effect on the application of SAK EMKM, is accepted. The business scale has a significance value of 0.912 , higher than 0.05 , and $t-0.100$. It shows that the business scale does not affect the implementation of SAK EMKM. Hypothesis H4, the business scale that positively affects the application of SAK EMKM, is rejected.

Business life has a significance value of 0.573 greater than 0.05 and $t-0.566$. It shows that the business scale does not affect the implementation of SAK EMKM. The hypothesis $\mathrm{H} 5$, the business scale that has a positive effect on the application of SAK EMKM, is rejected.

\section{DISCUSSION}

\section{The perception does not affect the implementation of SAK EMKM.}

Perception does not affect the application of SAK EMKM on sharia-based MSMEs in Kudus Regency. It means that there are still many sharia-based MSMEs doers who think that SAK EMKM has no significant impact on the progress of their business.

According to Clayton Alderfer, human needs are based on the needs of existence, social correlations, and growth in connection with the theory of needs. The perception variable itself is related to the theory of needs, namely the need for a social environment, where when MSMEs doers are in an environment that has a perception of the importance of implementing SAK EMKM based financial statements, it will lead to positive perceptions of the application of SAK EMKM.

Wahyuni (2017) and Syukrina (2018) supported these findings but contradicted with Febriyanti \&Wardhani (2018) and Kusuma \&Lutfiany (2018).

\section{Education has a positive effect on the implementation of SAK EMKM}

Education has a significant positive effect on SAK EMKM on sharia-based MSMEs in the Kudus Regency. It means that accounting knowledge is obtained at a higher level of education by starting the same department. Need theory, namely the need for existence and growth, is needed to maintain the existence and development of a business. A high level of education can make an individual more creative and innovative, which encourages his business to continue to exist and grow. The higher the level of education of a business owner, the higher the level of SAK EMKM. A business that has implemented SAK EMKM will make its management more structured so that the sustainability of its business will continue to be maintained and develop.

The results of this study support research conducted by Pratiwi and Hanafi (2016), Kusuma and Lutfiany (2018), and Susfayetti et al. (2018), which stated that education affects the application of SAK EMKM. However, in contrast to the research results conducted by 
Prajanto and Septriana (2018) and A.Romy (2018), which stated that education does not affect the application of SAK EMKM.

\section{Socialization has a positive effect on the implementation of SAK EMKM.}

Socialization affects the implementation of SAK EMKM in sharia-based MSMEs in the Kudus Regency. It means that the Socialization supports sharia-based MSMEs doers in understanding how to record and apply SAK EMKM. It is known that the Socialization obtained by sharia-based MSMEs doers in Kudus Regency either through media sources, seminars, or training is still low. It shows that the Socialization of SAK EMKM has not been done much. It is hoped that disseminating various media sources, both print, digital, or training from related institutions, can improve SAK EMKM for sharia-based MSMEs doers.

Based on the theory of needs, the need for socialization correlations can occur because of the social influence of the surrounding environment. SAK EMKM socialization provides information or training regarding SAK EMKM by related parties who can provide SAK EMKM socialization. The importance of Socialization for MSMEs doers to increase knowledge and motivate owners to improve the quality of financial reports made. Thus, MSMEs doers will easily be able to make capital loans.

The results of this study support research conducted by Kusuma and Lutfiany (2018), Syukrina (2018), and Badria and Diana (2018), whose research results state that Socialization affects the application of SAK EMKM. However, in contrast to the research conducted by Febriyanti and Wardhani (2018), which stated that Socialization does not affect the application of SAK EMKM.

\section{The size of the business does not affect the implementation of SAK EMKM.}

The business scale has no effect on the implementation of SAK EMKM on MSMEs in the Kudus Regency. It shows that many in Kudus Regency still feel that their businesses are still small and do not yet need financial reports by SAK EMKM.

The theory of needs which underlies that business scale is a need for growth/development, the size of the business can affect the thinking of entrepreneurs regarding complexity and the higher the business, so that the higher the business, it will encourage MSMEs doers to start thinking about the importance of financial reports to help assess financial performance in their business.

The results of this study are in line with research conducted by Susfayetti et al. (2018) and Prajanto and Septriyana (2018), which stated that the scale of the business does not affect the application SAK EMKM. However, this is not in line with Pratiwi and Hanafi's (2016) and Kamalia (2018).

\section{Age of business does not affect the implementation of SAK EMKM.}

Age of business does not affect the implementation of SAK EMKM on MSMEs in the Kudus Regency. It shows that business owners do not pay attention to accounting records even though they have been going on for a long time.

The result of this research is in line with research conducted by Susfayetti et al. (2017), Soraya and Mahmud (2016), and A. Putra (2018), which states that The Age of Business does 
not affect the application of SAK EMKM. However, Kamalia's research (2018) stated that Business life affects the application of SAK EMKM.

The theory of need for existence explains if an owner wants his business to exist, he must make decisions that can extend the life of his business. Good management and neat bookkeeping according to standards can increase the life of the business. The business's existence is maintained because the owner can know the development of his business with certainty. Longer business life shows excellent business development. Therefore, it takes SAK EMKM as the basis for accounting records for MSMEs. Age of business is an important tool for micro, small and medium enterprises (MSMEs), as it creates Networking (Vallaster et al., 2019).

\section{CONCLUSION}

This study concludes that perception, business scale, and business life do not affect the implementation of SAK EMKM on sharia-based MSMEs in the Kudus Regency. Education, Socialization has a significant positive effect on SAK EMKM on sharia-based MSMEs in the Kudus Regency. Businesses owned by Muslims in Kudus tend to focus more on philosophically well-behaved such as honesty, religious and business types tend to trade. Businesses tend to be closed and traditionally managed, so many MSMEs consider the making of financial statements not so important. Nevertheless, the owner of MSMEs also considers that education has an important role in managing its business.

\section{Limitation}

The limitations in this study are the independent variables, namely the owner's perception, education, Socialization, business scale, and age of the business, which are included in this study, can only influence the application of SAK EMKM by $28 \%$. It does not rule out the influence of other independent variables that are not included in this study. The scope of this research is only carried out on sharia-based MSMEs in Kudus Regency so that the generalization of the results of this study does not apply to other areas. Therefore, to get general conclusions, it is necessary to research by expanding the object of research.

Based on the above limitations, it can be suggested for further researchers to add other variables, which may be the factors that influence the application of SAK EMKM, such as understanding accounting. It is hoped that the understanding of accounting can support the application of SAK EMKM so that it can make accounting records according to standards and help increase the business of MSMEs doers in Kudus Regency. Further research is expected to expand the object of research. Research can be carried out in two or more areas or can also increase the research sample so that a comparison of respondents' perceptions can be obtained.

\section{REFERENCES}

Adino, I. (2019). Faktor-Faktor Yang Mempengaruhi Pemahaman Pelaku Umkm Terhadap SAK EMKM : Survey Pada UMKM Yang Terdaftar Di Dinas Koperasi Dan Ukm Kota $\begin{array}{llll}\text { Pekanbaru. Jurnal } & \text { Kkuntansi (3). }\end{array}$ https://doi.org/https://doi.org/10.35446/akuntansikompetif.v2i3.388 
Banks, M., \& Connor, J. O. (2017). Inside the whale ( and how to get out of there ): Moving on from two decades of creative industries research. European Journal of Cultural Studies, 20(6), 637-654. https://doi.org/10.1177/1367549417733002

Bhansing, P. V, Hitters, E., \& Wijngaarden, Y. (2017). Passion Inspires : Motivations of Creative Entrepreneurs in Creative Business Centres in the Netherlands. The Journal of Entrepreneurship, 27(1), 1-4. https://doi.org/10.1177/0971355717738589

Cerneviciute, J., \& Strazdas, R. (2018). Teamwork Management in Creative Industries:Factor Influenzing Productivity. Entrepreneurship and Sustainability Issues, 6(2), 503-516.

Delima, Z. M., \& Zuliyati. (2020). Improvement Of Micro, Small, And Medium Enterprise ( MSME ) Performance On Food And Beverages In Kudus Regency Analysis Of Intellectual Capital Management Success Through The Improvement Of Micro, Small, And Medium Enterprise ( MSME ) Performance On F. Researchgate, Conference Paper, 19 March 2020. https://doi.org/10.4108/eai.24-10-2018.2280528

Galuh Artika Febriyanti, A. S. W. (2018). The Impact Of Perception, Education Level, and Sosialization Towards The Implementation of SAK EMKM: A Case Of Surabaya MSME's Pengaruh. Jurnal Ilmiah ESAI Volume, 12(2), 112-127. https://doi.org/http://dx.doi.org/10.25181/esai.v12i2.1096 Jurnal

Kamila, A. (2017). Analisis Faktor-Faktor yang Memengaruhi Keinginan Usaha Mikro, Kecil, dan Menengah dalam Menerima SAK EMKM (Studi pada UMKM di Kabupaten Kudus). Accounting and Business Information Systems Journal, 5(1). https://journal.ugm.ac.id/abis/article/view/59294

Kazungu, I. (2020). Network Linkages and Performance of Exporting Micro and Small Enterprises in Dar es Salaam, Tanzania: Perspectives in the Handicraft Industry. Global Business Review. https://doi.org/10.1177/0972150920934433

Reno, M., \& Rahman, F. (2019). Creative Economy Based On Syaria As An Efford To Increase Communities Welfare : Case Study at BAPPEDA, East Java Province, 2019. MIQOT, 43(2), 149-166. https://doi.org/http://dx.doi.org/10.30821/miqot.v43i2.674

Stasiulis, N., \& Technical, V. G. (2017). The Idea of The Creative Society and The Development of Creative Industries. Economics and Sociology, 10(2), 217-226. https://doi.org/10.14254/2071-789X.2017/10-2/16

UU RI No 20 Th 2008 Tentang UMKM, (2008).

Vallaster, C., Kraus, S., Lindahl, J. M. M., \& Nielsen, A. (2019). Ethics and entrepreneurship: A bibliometric study and literature review. Journal of Business Research, 99(April 2018), 226-237. https://doi.org/10.1016/j.jbusres.2019.02.050

Weingarten, E., \& Meyer, M. W. (2020). Human Experts Outperform Technology in Creative Markets. She Ji: The Journal of Design, Economics, and Innovation, 6(3), 301-330. https://doi.org/10.1016/j.sheji.2020.07.004

Yuriy B, Tetyana V, Olena K, G. S., \& Tomas. (2019). The Creative Industry as a Factor in The Development of the Economy: Dissemination of Europea Experience in The Countries with Economies in Transition. Creativity Studies, 12(1), 75-101. 